\title{
De doorwerking van lokaal rekenkameronderzoek: een empirische zoektocht naar succesfactoren van gebruik
}

Sjoerd Keulen

Doorwerking van rekenkamerrapporten heeft in de wetenschappelijke literatuur weinig aandacht gekregen. In dit artikel zijn allereerst met behulp van bestuurskundige literatuur verschillende vormen van doorwerking onderscheiden en zijn factoren onderscheiden die het gebruik van evaluaties stimuleren. Dit theoretisch kader is vervolgens gebruikt voor empirisch onderzoek naar de doorwerking van rekenkameronderzoek. Van 20 gemeenten is met behulp van doorwerkingsrapporten van rekenkamers onderzocht in hoeverre de aanbevelingen doorwerking hebben gehad. Uit 176 publicaties werd 94\% van de 1216 aanbevelingen overgenomen door de gemeenteraad. Hiermee is de procedurele doorwerking hoog. Van de 731 aanbevelingen die bij 17 gemeenten waren na te gaan, melden de rekenkamers dat $58 \%$ geheel was geïmplementeerd, $19 \%$ gedeeltelijk en $15 \%$ niet of anders opgepakt. De drie categorieën succesfactoren uit de wetenschappelijke literatuur waren zichtbaar in de rekenkamerpraktijk. Dit geldt het sterkst voor doorwerkingsfactoren die te maken hebben met de evaluatiekwaliteit, met name de factoren communicatiekwaliteit, heldere aanbevelingen, tijdigheid en relevantie voor de besluitvormer. Van factoren in de context van het onderzoek en de besluitvorming erover zijn het commitment van de organisatie en het politieke klimaat het belangrijkst. Tot slot bevordert als katalysator het betrekken van stakeholders de doorwerking. Het artikel sluit uit af met lessen voor de praktijk om doorwerking van rekenkamerrapporten te bevorderen.

Relevantie voor practitioners: dit artikel presenteert zes lessen om de doorwerking van aanbevelingen van rekenkamers te vergroten. Ten eerste is goed contact met de gemeenteraad belangrijk, ten tweede een helder geschreven en gedegen rapport en duidelijke communicatie. Tijdigheid en relevantie (voor de gemeenteraad) zijn de derde voorspeller voor doorwerking. Ten vierde helpt heldere besluitvorming. Les 5: aanbevelingen worden sneller geïmplementeerd als ambtenaren bekend zijn met de rekenkamer. Als laatste les moet iemand bijhouden of de aanbevelingen ook daadwerkelijk worden geïmplementeerd.

\section{Inleiding}

Nederlandse gemeenten en provincies hebben sinds 2005, respectievelijk 2006, de wettelijke verplichting om een rekenkamer in te richten. ${ }^{1}$ Toen in 2011 voor de 
minister van Binnenlandse Zaken en Koninkrijksrelaties (BZK) de staat van decentrale rekenkamers geëvalueerd werd, werd hem een flets beeld van rekenkamerland gepresenteerd. Er bestonden gemeenten met slapende rekenkamers, het budget voor de lokale rekenkamers liep terug en de impact van de onderzoeken was onduidelijk (Van der Mark e.a., 2011). 'Rekenkamerrapporten [worden] dikwijls te weinig doorvertaald naar concrete beleidswijzigingen', schreven de onderzoekers, en dit leidde weer tot onvrede in gemeenteraden over het uitblijven van die doorvertaling. Van de ondervraagde raadsleden, griffiers en collegeleden was $40 \%$ enigszins tevreden tot ontevreden over de doorwerking van de rekenkamerrapporten. In 2015 lanceerde toenmalig minister Plasterk daarom een actieplan om de lokale rekenkamers te versterken (Kamerstukken II 2014/15, 34000-VII, nr. 54). Een van de speerpunten werd doorwerking: de mate waarin onderzoeksresultaten worden vertaald in door de gemeenteraad overgenomen aanbevelingen en idealiter leiden tot aanpassing van het beleid.

Doorwerking is daarmee een typisch rekenkamerthema dat in de wetenschappelijke literatuur maar weinig aandacht heeft gekregen. In dit artikel wordt dit onderzocht met de volgende hoofdvraag:

\section{Welke factoren verklaren de doorwerking van lokaal rekenkameronderzoek?}

Zo wordt geprobeerd de succesfactoren van doorwerking te achterhalen op basis van theorie en empirie. Allereerst wordt besproken wat doorwerking is en wat we specifiek weten van doorwerking van rekenkameronderzoek. In de volgende paragraaf wordt uitgelegd dat rekenkameronderzoek ook kan worden opgevat als een vorm van evaluatie. Evaluatie is internationaal een groot en divers onderzoeksveld. Aan de hand van wetenschappelijke literatuur naar gebruik van evaluaties zijn de meest genoemde factoren die doorwerking stimuleren verzameld. Deze factoren worden in de vierde paragraaf geconfronteerd met de empirie: een set van twintig doorwerkingsrapporten die rekenkamers zelf hebben opgesteld. Voor elk van de rapporten is systematisch onderzocht in hoeverre de factoren voorkomen. Tot slot wordt in de discussie en conclusie besproken welke implicaties deze analyse heeft voor toepassing in de praktijk van rekenkamers en worden er concrete lessen getrokken om de doorwerking van rekenkamerrapporten te vergroten.

\section{Doorwerking van rekenkamerrapporten: definitie en onderzoeksresultaten}

Doorwerking is een ambigu begrip, dat op verschillende manieren gedefinieerd kan worden en mede hierdoor lastig te meten is. De bestuurskundigen Bekkers, Fenger, Homburg en Putters (Bekkers e.a., 2004) waren een van de eersten in Nederland die hebben onderzocht hoe adviezen doorwerkten in beleid. Zij maakten hierbij onderscheid in vier verschillende soorten doorwerking. Allereerst is er instrumentele doorwerking, waarbij je directe verandering in gedrag van organisaties of individuen ziet die in lijn is met het advies. Ten tweede conceptuele 
doorwerking, waarbij het advies leidt tot andere kennis of opvattingen van individu of organisatie. Als derde is er agenderende doorwerking, waarbij het advies een nieuw thema op de politieke of maatschappelijke agenda plaatst. Tot slot is er politiek-strategische doorwerking, waarbij het advies wordt gebruikt om de eigen machtspositie te versterken (Bekkers e.a., 2004: 24).

In 2008 pleitten de bestuurskundigen Hakvoort en Klaassen voor meer aandacht voor doorwerking en voor het hanteren van verschillende perspectieven op doorwerking van rekenkameronderzoek. Zij onderscheidden voor rekenkameronderzoek drie vormen: procedurele doorwerking, gericht op de procedurele stappen in het onderzoek als de bestuurlijke reactie en de raadsbehandeling. Ten tweede beleidsmatige doorwerking, waarin bestaande beleidsprogramma's en begrotingen worden aangepast. En als derde maatschappelijke doorwerking, de mate waarin de aanpassingen op basis van de aanbevelingen ook daadwerkelijk tot maatschappelijke verbetering leiden (Hakvoort \& Klaassen, 2008).

Vanuit de Nederlandse Vereniging van Rekenkamers en Rekenkamercommissies (NVRR) kwam er door het actieplan van de minister van BZK uit 2015 ook meer aandacht voor doorwerking. In twee handreikingen (NVRR, 2015; 2018) zijn op basis van de literatuur van met name Bekkers e.a. (2004) niveaus van doorwerking onderscheiden en is er een 10-stappenplan ontwikkeld om deze doorwerking te bepalen. Het idee was dat rekenkamers door de eigen doorwerking te onderzoeken hun kwaliteit zouden verbeteren.

De ambiguïteit van het begrip doorwerking maakt het ook lastig meetbaar, zo blijkt iedere keer als de prestaties van lokale rekenkamers door het Ministerie van BZK geëvalueerd worden. Al in de eerste evaluatie in 2007 bleek dat weliswaar in de meerderheid van de gevallen (62\%) de aanbevelingen van rekenkamer(commissie)s werden overgenomen door raad en staten, maar dat tegelijkertijd in slechts $39 \%$ van de gevallen de rapporten ook daadwerkelijk waren geagendeerd om door de volksvertegenwoordigers te bespreken (Brandsen e.a., 2007). Blijkbaar werden veel rekenkamerrapporten zonder debat of bespreking afgehamerd. Daarmee leek er wel sprake te zijn van een vorm van procedurele doorwerking, maar bleef het onduidelijk of de rapporten ook zorgden voor aanpassingen in het beleid (beleidsmatige of instrumentele doorwerking) en hadden de rapporten blijkbaar ook geen agenderende functie. Uit een enquête onder leden van rekenkamer(commissie)s in 2010 sprak een positief zelfbeeld: de leden scoorden de mate waarop hun aanbevelingen werden overgenomen met het rapportcijfer 7,6 , en gaven een 6,9 voor de daadwerkelijke implementatie van deze aanbevelingen (Van der Zee \& De Jong, 2010).

In de tweede BZK-evaluatie uit 2011, van zowel lokale als provinciale rekenkamers, werd geprobeerd doorwerking duidelijker te definiëren: 'Wanneer de raadsen statenleden de conclusies en aanbevelingen onderschrijven en ook het college de aanbevelingen (deels) overneemt, is er sprake van doorwerking.' Hoe hoger de doorwerking hoe hoger de effectiviteit werd geacht. Hierbij werd onderscheid gemaakt tussen twee vormen van doorwerking: instrumentele doorwerking en conceptuele 
doorwerking, waarbij Bekkers e.a. (2004) gevolgd werd. In de instrumentele doorwerking was ten opzichte van de vorige evaluatie een stijgende lijn te zien: in $70 \%$ van de gevallen werden de aanbevelingen door de raad overgenomen, en in $81 \%$ van de gevallen werden de rapporten ook door de raad of staten behandeld. Ook over de conceptuele doorwerking werd positief gedacht, al schatten rekenkamerleden (+/- 75\%) dat wel aanzienlijk hoger in dan de ambtelijke organisatie (39\%). In dit onderzoek werd vooral de perceptie van doorwerking gemeten (Van der Mark e.a., 2011).

Deze opgaande lijn werd daarna niet vastgehouden. In een nieuwe BZK-evaluatie van lokale rekenkamers uit 2015 was slechts $40 \%$ van de griffiers (zeer) tevreden over de doorwerking en dit percentage was zelfs nog $3 \%$ lager als het ging om de daadwerkelijke implementatie van rekenkameraanbevelingen door de gemeente (Van der Mark \& De Wal, 2015). Ook in een laatste evaluatie voor het ministerie uit 2019, ditmaal op basis van gesprekken, was er bij gemeenten bezorgdheid over de doorwerking. Redenen die daarvoor gegeven werden, waren de kwaliteit van de aanbevelingen, maar ook dat bestuur en ambtenaren geen zin hadden om de aanbevelingen te implementeren. Dat kon vaak ongestraft, doordat afspraken over monitoring van de aanbevelingen ontbraken, waardoor de aanbevelingen vanzelf uit het zicht raakten (Werkgroep lokale rekenkamers, 2019).

Wanneer we de hele periode overzien, komt uit de evaluaties een wisselend beeld van de doorwerking van rekenkamerrapporten naar voren. Aanvankelijk leek deze in de perceptie van de respondenten toe te nemen, maar vanaf 2015 wordt de toon van de evaluaties hierover somberder. Alhoewel dat in de verschillende onderzoeken door het ministerie niet werd geproblematiseerd, kwam dat ook doordat de enquêtes steeds wisselende definities en meetmethoden van doorwerking gebruikten. Van wat voor vorm van doorwerking er nu sprake was, bleek op basis van enquêtes eigenlijk niet vast te stellen. Bovendien bleken de leden van de rekenkamer over het algemeen positiever over de conceptuele doorwerking dan de ambtenaren die de aanbevelingen ter hand moesten nemen. Of na de aanvaarding van de aanbevelingen van de rekenkamer ook daadwerkelijk het beleid veranderde, werd in de enquêtes niet nagegaan en evenmin werd dit op andere manieren gerapporteerd. In hoeverre er werkelijk sprake is van doorwerking van rekenkameraanbevelingen in de vorm van aanpassingen van beleid, blijft de vraag.

\section{Literatuur over gebruik van evaluaties}

Hoe evaluaties worden gebruikt, is een van de meest onderzochte thema's in onderzoek naar evaluaties (Højlund, 2014). Net als bij doorwerking worden daarbij vaak verschillende soorten van gebruik onderscheiden: instrumenteel, procedureel en symbolisch gebruik (bijv. Shulha \& Cousins, 1997). Daarnaast bestaan er verschillende literatuurstudies naar factoren die de mate van gebruik van evaluaties proberen te verklaren (zie bijv. Johnson e.a., 2009; Alkin \& King, 2017). De studie van Cousins en Leithwood (1986) vormt hierbij vaak de basis. In 
deze studie werden op basis van een meta-analyse zes factoren bepaald die implementatie van evaluatieresultaten bevorderen en nog eens zes factoren die besluiten beleidsvorming bevorderen. De mate van invloed van de verschillende zaken verschilde nogal. Cousins en Leithwood (1986) concludeerden dat evaluaties het vaakst gebruikt werden als ze methodologisch correct waren, gebruikers voor hen belangrijke besluiten moesten nemen en hierbij op de data uit de evaluatie konden bouwen, als de bevindingen aansloten bij de overtuigingen en verwachtingen van de gebruiker, de gebruikers betrokken waren bij het evaluatieproces en zich gecommitteerd hadden aan de uitkomsten, en als de onderzoeksresultaten niet te veel conflicteerden met andere data.

Ondanks de grote aandacht voor gebruik van evaluaties weten we uit beroemd bestuurskundig onderzoek (Patton, 1997; Pawson \& Tilley, 1997) ook dat evaluaties lang niet altijd bijdragen aan de aanpassing van beleid. Zowel Patton als Pawson en Tilley schreven dit toe aan een te rationele benadering van evaluaties, die te veel uitging van een positivistische kijk op evaluaties: wat niet goed gaat, wil je verbeteren. Zeker in een politieke context, de context waarin rekenkameronderzoek gedaan wordt, is dat niet per definitie een gegeven. Daarom pleitten Pawson en Tilley voor een meer context-gebonden manier van evalueren, de zogenaamde realistic evaluation (Pawson \& Tilley, 1997). Patton schreef in de jaren daarna diverse bijdragen over utilization-focused evaluation. Dit zijn evaluaties die vanaf de eerste stap gericht zijn op gebruik en acceptatie en daardoor ook veel aandacht hebben voor de persoon en organisatie van de gebruiker (Patton, 2011).

De aandacht voor de context van evaluaties is in de jaren daarna alleen maar toegenomen. Ook werd er bijvoorbeeld meer gekeken naar de druk op een organisatie als voorspeller voor het gebruik van evaluaties (Højlund, 2014). Dit wordt ook gereflecteerd in de literatuurstudies die het onderzoek van Cousins en Leithwood (1986) hebben herhaald en aangevuld. Sinds de studie van Shulha en Cousins (1997) gaat steeds meer aandacht naar zowel de (organisatie)context als de persoon van de evaluator. Zij zagen dat de evaluatiecontext belangrijk was voor de mate van gebruik en stelden vast dat organisaties als gevolg van de evaluaties konden veranderen. Door de groeiende aandacht voor deze sensitieve kant van evalueren wonnen de communicatieve en faciliterende kanten van de evaluator ook meer aan kracht als factoren die de invloed van evaluaties bepaalden.

In een laatste herhaling van de literatuurstudie van Cousins en Leithwood (1986) door Johnson e.a. (2009) voegde men aan de verklarende factoren het betrekken van stakeholders toe als nieuwe factor om gebruik te verklaren. Zij benoemden dit als een aparte factor, maar deze lijkt in de praktijk meer te werken als een katalysator die zorgt dat andere factoren voor gebruik worden versterkt, doordat het begrip van en over de evaluatie wordt versterkt. Als we kijken naar onderzoek dat gericht is op factoren die het gebruik van evaluaties belemmeren, zien we dat daar vaak dezelfde (spiegelbeeldige) factoren worden gevonden, zoals gebrekkige kennis, gebrek aan ervaring en percepties als de context van de organisatie en het politieke karakter van de organisatie (Taut \& Alkin, 2003; Fleischer \& Christie, 2009). 
Vanaf het begin van de 21ste eeuw hebben diverse auteurs gepleit om het begrip gebruik (use, utilization) te verbreden tot de invloed die evaluaties hebben op veranderingen. Het beroemdste voorbeeld komt van Henry en Mark (2003), die evaluaties als bron van invloed onderzochten door te kijken naar de intenties tot beïnvloeding die de opstellers hadden. Deze auteurs vroegen ook aandacht voor de soms lange tijdsspanne van beleidsverandering en daarmee van doorwerking. Onder invloed kon ook onbedoelde invloed vallen of doorwerking na heel lange tijd. Deze zaken zijn bijzonder lastig te meten en causaal te verbinden aan de evaluaties (Alkin \& Taut, 2003). Daarom worden deze factoren in dit artikel buiten beschouwing gelaten en wordt het meer begrensde begrip gebruik onderzocht.

Op basis van de literatuurstudies ontstaat daarmee een overzicht van de drie categorieën. De eerste categorie wordt in de literatuur tamelijk verwarrend omschreven als implementatie van de evaluatie. Hier is gekozen voor de term evaluatiekwaliteit. Deze categorie omvat namelijk factoren die vooral intern gericht zijn, zoals de kwaliteit van de evaluatie en van de evaluator zelf. Veelal kan de evaluator die factoren zelf beïnvloeden. Denk bijvoorbeeld aan de methodologische kwaliteit. De tweede categorie 'context' is meer extern gericht en omvat factoren die betrekking hebben op de context waarin de evaluatie wordt uitgevoerd en behandeld. De derde categorie 'betrekken van stakeholders' is een toevoeging op basis van een publicatie van Johnson e.a. (2009) en eigenlijk een soort katalysator: door het actief betrekken van stakeholders nemen de andere factoren van gebruik toe.

In tabel 1 zijn alle verklarende factoren bijeengebracht. De volgorde van de factoren binnen de categorieën is gebaseerd op de meest recente systematische literatuurstudie naar evaluatiegebruik (Johnson e.a., 2009). Hierbij worden de invloedrijkste factoren als eerste genoemd. Een deel van deze factoren komt overeen met factoren die in de Nederlandse literatuur over doorwerking van rekenkameronderzoek worden gehanteerd. Deze auteurs baseerden zich hierbij op andere literatuur (Hoekstra, 2013; Lemmens, 2014). In de derde kolom staat welke literatuurstudies naar het gebruik van evaluaties deze factoren onderschrijven.

\section{Methodologie voor het onderzoek naar doorwerkingsrapporten}

Om te onderzoeken in hoeverre de factoren die het gebruik van evaluaties verklaren ook daadwerkelijk empirisch voorkomen, zijn doorwerkingsrapporten van rekenkamer(commissie)s gebruikt. Doorwerkingsrapporten zijn rapporten waarin de rekenkamer terugkijkt en probeert vast te stellen in hoeverre de aanbevelingen in eerder onderzoek zijn overgenomen en geïmplementeerd en zo tot verandering van beleid hebben geleid. De reikwijdte van deze onderzoeken verschilt, bijvoorbeeld in periode of in het aantal onderzochte rapporten (soms één, soms een thema, soms alle rapporten van de afgelopen periode). 
Tabel 1 Factoren die gebruik van evaluaties verklaren

\begin{tabular}{|c|c|c|}
\hline Categorie & Factor & Vindplaats \\
\hline \multirow[t]{8}{*}{ Evaluatiekwaliteit } & $\begin{array}{l}\text { Communicatiekwaliteit: helderheid } \\
\text { van het onderzoek, toewijding om de } \\
\text { bevindingen te verspreiden }\end{array}$ & $\begin{array}{l}\text { Cousins \& Leithwood (1986); John- } \\
\text { son e.a. (2009); Fleischer \& Christie } \\
\text { (2009); Alkin \& King (2017) }\end{array}$ \\
\hline & $\begin{array}{l}\text { Gedetailleerde, op feiten gebaseerde, } \\
\text { bruikbare aanbevelingen }\end{array}$ & Cousins \& Leithwood (1986) \\
\hline & Tijdigheid van de evaluatie & $\begin{array}{l}\text { Cousins \& Leithwood (1986); John- } \\
\text { son e.a. (2009) }\end{array}$ \\
\hline & Competentie van de evaluator & $\begin{array}{l}\text { Shulha \& Cousins, 1997; Johnson e.a. } \\
\text { (2009) }\end{array}$ \\
\hline & Methodologische kwaliteit & $\begin{array}{l}\text { Cousins \& Leithwood (1986); John- } \\
\text { son e.a. (2009); Fleischer \& Christie } \\
\text { (2009); Alkin \& King (2017) }\end{array}$ \\
\hline & $\begin{array}{l}\text { Bevindingen van de evaluatie stroken } \\
\text { met verwachtingen van de gebruiker }\end{array}$ & $\begin{array}{l}\text { Cousins \& Leithwood (1986); John- } \\
\text { son e.a. (2009) }\end{array}$ \\
\hline & Relevantie voor de besluitvormer & $\begin{array}{l}\text { Cousins \& Leithwood (1986); John- } \\
\text { son e.a. (2009); Fleischer \& Christie } \\
\text { (2009); Alkin \& King (2017) }\end{array}$ \\
\hline & Geloofwaardigheid van de evaluator & $\begin{array}{l}\text { Johnson e.a. (2009); Alkin \& King, } \\
2017\end{array}$ \\
\hline \multirow[t]{6}{*}{ Context } & $\begin{array}{l}\text { Persoonlijke eigenschappen van de } \\
\text { gebruiker }\end{array}$ & $\begin{array}{l}\text { Cousins \& Leithwood (1986); John- } \\
\text { son e.a. (2009); Alkin \& King (2017) }\end{array}$ \\
\hline & $\begin{array}{l}\text { Commitment en het openstaan van } \\
\text { de organisatie voor evaluaties }\end{array}$ & $\begin{array}{l}\text { Cousins \& Leithwood (1986); Shulha } \\
\text { \& Cousins, I997; Johnson e.a. (2009); } \\
\text { Fleischer \& Christie (2009); Alkin \& } \\
\text { King (2017) }\end{array}$ \\
\hline & Politiek klimaat & $\begin{array}{l}\text { Cousins \& Leithwood (1986); John- } \\
\text { son e.a. (2009); Shulha \& Cousins } \\
\text { (1997) }\end{array}$ \\
\hline & $\begin{array}{l}\text { Belang van het besluit dat op basis } \\
\text { van de evaluatie genomen wordt }\end{array}$ & $\begin{array}{l}\text { Cousins \& Leithwood (1986); John- } \\
\text { son e.a. (2009); Alkin \& King, (2017) }\end{array}$ \\
\hline & $\begin{array}{l}\text { Geringe tegenstrijdigheid van de eva- } \\
\text { luatie met andere al beschikbare } \\
\text { informatie }\end{array}$ & $\begin{array}{l}\text { Cousins \& Leithwood (1986); John- } \\
\text { son e.a. (2009); Alkin \& King (2017) }\end{array}$ \\
\hline & Informatiebehoefte van de gebruiker & $\begin{array}{l}\text { Cousins \& Leithwood (1986); John- } \\
\text { son e.a. (2009); Alkin \& King (2017) }\end{array}$ \\
\hline $\begin{array}{l}\text { Betrekken van } \\
\text { stakeholders bij } \\
\text { het onderzoek }\end{array}$ & $\begin{array}{l}\text { Betrokkenheid zorgt voor commit- } \\
\text { ment, betere communicatie, hogere } \\
\text { geloofwaardigheid van de evaluatie, } \\
\text { beter begrip van de bevindingen, } \\
\text { meer (soorten van) gebruik }\end{array}$ & $\begin{array}{l}\text { Shulha \& Cousins (1997); Johnson } \\
\text { e.a. (2009); Alkin \& King, 2017; } \\
\text { Fleischer \& Christie (2009) }\end{array}$ \\
\hline
\end{tabular}

In de verschillende doorwerkingsonderzoeken zijn drie typen te onderscheiden. Allereerst zijn er onderzoeken die alleen kijken naar de raadsbehandeling van het rekenkameronderzoek en vaststellen of (en hoeveel) aanbevelingen door het college worden overgenomen en door de raad worden aanvaard in een raadsbesluit. Dit type onderzoek karakteriseren we als procedurele werkingsonderzoeken. 
Het tweede type noemen we opvolgingsonderzoek. Hierbij wordt veelal op basis van zelfrapportage door het college of door een quickscan van raadsinformatiebrieven in kaart gebracht of er door het college vervolgacties op basis van de aanbevelingen zijn ondernomen. Hierbij wordt geen onderscheid gemaakt naar de vorm van doorwerking dat het rekenkameronderzoek heeft gehad en welke factoren uit het rekenkameronderzoek hiervoor hebben gezorgd. Dit gebeurt wel in de derde en meest vergaande vorm, die we hier doorwerkingsonderzoek noemen. Hierbij wordt vaak gebruikgemaakt van de literatuur van Bekkers e.a. (2004) of een afgeleide hiervan in de vorm van de handreikingen van de NVRR (2015; 2018).

Voor de empirische toets zijn doorwerkingsrapporten van twintig rekenkamers c.q. gemeenten geselecteerd. Hiervoor is de bibliotheek van de NVRR gebruikt, die openbaar toegankelijk is op www.nvrr.nl. Voor de periode 2009-2019 zijn alle beschikbare doorwerkingsrapporten geselecteerd. Uitgangspunt voor de selectie was dat alle gemeentelijke indelingsklassen van het Ministerie van BZK en gemeenten uit alle provincies in de sample zaten. Hiertoe zijn via een Googlezoekopdracht nog enige aanvullende doorwerkingsrapporten toegevoegd uit dezelfde periode. Zo ontstond een sample van twintig gemeenten waarin alle provincies en - met uitzondering van de allerkleinste gemeenten (kleiner dan 8000 inwoners) - alle indelingsklassen vertegenwoordigd waren. De noordelijke provincies zijn hierbij iets ondervertegenwoordigd met slechts één rapport voor Friesland. Dat geldt ook voor Zeeland, terwijl de provincie Utrecht wat oververtegenwoordigd is met vier rapporten. De geselecteerde rapporten zijn desondanks een goede dwarsdoorsnede van het doorwerkingsonderzoek van Nederlandse gemeentelijke rekenkamer(commissie)s.

\section{De drie typen van doorwerkingsonderzoek}

In deze paragraaf worden de drie typen van doorwerkingsonderzoek geanalyseerd zoals die voorkwamen in de rapporten van de twintig rekenkamer(commissie)s. Eerst wordt de procedurele werking besproken, vervolgens de opvolging en tot slot komen de vormen van doorwerking die de rekenkamer(commissie)s zelf rapporteren, aan bod.

\subsection{Type 1: Procedurele werking}

De twintig rekenkamer(commissie)s hebben in totaal 176 eigen publicaties onderzocht op procedurele werking. Dit waren vrijwel altijd rekenkamerrapporten; rekenkamerbrieven kwamen nauwelijks voor. In deze publicaties stonden in totaal 1216 aanbevelingen. Van deze aanbevelingen werd $94 \%$ door de gemeenteraden overgenomen, veelal in de vorm van een raadsbesluit. Bij zeven onderzochte gemeenten werden door de gemeenteraad alle aanbevelingen overgenomen. Bij de overige dertien werd er af en toe een aanbeveling niet overgenomen, maar gebeurde dat toch zeer sporadisch (zie tabel 2). In de drie gemeenten waar het vaakst aanbevelingen niet werden overgenomen, verwierp de raad zo'n 30 tot 
Tabel 2 Door de gemeenteraad overgenomen aanbevelingen

\begin{tabular}{llll}
\hline & $\begin{array}{l}\text { Aantal } \\
\text { gemeenten }\end{array}$ & $\begin{array}{l}\text { Aantal } \\
\text { publicaties }\end{array}$ & $\begin{array}{l}\text { Aantal } \\
\text { aanbevelingen }\end{array}$ \\
\hline $\begin{array}{l}\text { Totale sample } \\
\begin{array}{l}\text { Overgenomen aanbevelingen door } \\
\text { de gemeenteraad }\end{array}\end{array}$ & 20 & 176 & 1216 \\
\hline
\end{tabular}

$35 \%$ van de aanbevelingen. We kunnen daarom concluderen dat van de twintig onderzochte gemeenteraden vrijwel alle de aanbevelingen van hun rekenkamers overnemen.

Een factor die door sommige rekenkamers als Breda en Utrecht in hun rapport expliciet wordt genoemd als reden voor een hoge doorwerking, is het door de rekenkamer zelf opstellen van een raadsvoorstel. Bij rekenkamer(commissie)s die dit doen, is het aantal door de gemeenteraad overgenomen aanbevelingen opvallend hoog. Doordat de rekenkamer zelf het initiatief neemt, is het niet afhankelijk van de oplettendheid of welwillendheid van griffie, raad(scommissie) of college om het rapport en aanbevelingen te agenderen en goed te verwoorden. In gemeenten waar de rekenkamer dit niet zelf doet, komt het vaker voor dat een rapport niet door de raad behandeld wordt.

\subsection{Type 2: Opvolgingsonderzoek}

De twintig rekenkamer(commissie)s hebben in hun terugblikken niet de opvolging van alle aanbevelingen onderzocht. Ook was het na bestudering van hun rapporten niet altijd duidelijk in hoeverre aanbevelingen waren geïmplementeerd of niet. In totaal bleven er bij zeventien gemeenten 731 aanbevelingen over, waarvan is onderzocht of deze door de gemeentelijke organisatie en door het college van $\mathrm{B} \& \mathrm{~W}$ waren geïmplementeerd. In $58 \%$ van de gevallen meende de rekenkamer(commissie)s dat dit geheel het geval was, in $19 \%$ gedeeltelijk, en $15 \%$ van de aanbevelingen was niet geïmplementeerd. In $8 \%$ van de gevallen was er iets anders mee gebeurd of was er onvoldoende tijd verstreken om vast te kunnen stellen of de aanbeveling werd geïmplementeerd. Kortom, in $77 \%$ van alle aanbevelingen menen de rekenkamer(commissie)s dat hun aanbevelingen geheel of gedeeltelijk zijn geïmplementeerd. Hierbij moet wel een belangrijke kanttekening worden gemaakt. In de onderzochte rapporten werd voor de meting soms alleen gebruikgemaakt van gegevens over opvolging die door de gemeentelijke ambtelijke organisatie zelf waren aangeleverd. Dat betekent hoogstwaarschijnlijk dat er een (aanzienlijke) vertekening zit in de gegevens, en dat het percentage overgenomen aanbevelingen in werkelijkheid lager is dan $77 \%$.

De implementatie van de aanbevelingen in het oog houden blijkt in de praktijk lastig. Acht rekenkamers melden dat dit in hun gemeente niet gebeurt; niet zelden bevat het doorwerkingsrapport een aanbeveling aan de gemeenteraad om dit wel te gaan doen. De jaarstukken worden hierbij vaak als logisch instrument genoemd, maar in de praktijk wordt dit zelden doorgevoerd, zo blijkt uit de door- 
werkingsonderzoeken. Slechts uit twee rapporten blijkt dat ofwel de ambtelijk secretaris van de rekenkamercommissie ofwel de griffie de implementatie van aanbevelingen volgt. In deze beide gemeenten ligt het aantal geïmplementeerde aanbevelingen duidelijk hoger dan gemiddeld. Dat vreemde ogen dwingen, lijkt in ieder geval op te gaan in Cranendonck, waar de griffie bij uitzondering voor één rapport - dat weliswaar ook sterk ging over het functioneren van de raad - bijhield hoe dit rapport werd opgevolgd. Dit bleek ook het enige rekenkamerrapport in deze gemeente te zijn waarvan vrijwel alle aanbevelingen waren geïmplementeerd. Een andere manier om doorwerking te bevorderen is de verplichting in de Utrechtse verordening op de rekenkamer, dat het college binnen zes weken na de besluitvorming over een rekenkamerrapport een plan van aanpak aan de gemeenteraad moet presenteren over hoe zij het raadsbesluit gaat implementeren.

\subsection{Type 3: Zelfrapportage over doorwerking}

In het derde type doorwerkingsonderzoek onderzoeken rekenkamers de wijze waarop de doorwerking heeft plaatsgevonden. Hierbij wordt vaak onderscheid gemaakt tussen verschillende vormen van doorwerking. Er zijn verschillende rekenkamers die zich hiervoor door Bekkers e.a. (2004) hebben laten inspireren om de diverse vormen van doorwerking na te gaan. Veelal maken ze hierbij gebruik van de NVRR-handreikingen (2015; 2018). Instrumentele doorwerking waarbij de gemeentelijke organisatie in lijn met het advies verandert, keert vaak terug, niet verrassend gezien de $77 \%$ geïmplementeerde aanbevelingen. Of dit ook leidde tot maatschappelijke verandering, de derde vorm van doorwerking, blijkt vaak lastig te meten. De rekenkamer Utrecht rapporteert als voorbeeld dat dit in $60 \%$ van de aanbevelingen is gelukt. Dat stelde de rekenkamer vast op basis van raadstukken, de eigen evaluaties waarmee ieder onderzoek wordt afgesloten en door in verdiepende interviews met ambtenaren terug te blikken op het implementatietraject van de aanbevelingen.

Zes rekenkamerrapporten laten conceptuele doorwerking zien, waarbij de opvatting van de gemeente wijzigt door het rapport. Agenderende doorwerking is niet systematisch bijgehouden door de rekenkamers, maar enkele rekenkamers rapporteren dat hun onderzoeken agenderend zijn geweest; heel vaak ging het hierbij om de voorbereiding van drie grote decentralisaties in het sociale domein in 2015. Politiek -strategische doorwerking, waarbij het rapport gebruikt wordt om de eigen machtspositie te versterken (Bekkers e.a., 2004: 24), is evenmin onderzocht door de rekenkamers. Een laatste vorm van doorwerking die door sommige rekenkamers onderscheiden wordt, is conceptuele of indirecte doorwerking, waarbij het rapport ook doorwerking heeft op andere terreinen. Vier rekenkamers zien deze vorm van doorwerking terug, twee rekenkamers zien deze vorm nadrukkelijk niet, en de overige zeggen er niks over.

\section{Doorwerkingsfactoren die gebruik van rekenkamerrapporten bevorderen}

In deze paragraaf onderzoeken we in hoeverre de verschillende doorwerkingsfactoren uit de literatuur daadwerkelijk terugkomen in de doorwerkingsrapporten 
van de onderzochte rekenkamers. Hiervoor zijn rapporten van elf van de twintig rekenkamers bruikbaar, te weten die van de gemeenten Breda, Cranendonck, Den Bosch, Deventer, Doetinchem, Ede, Hilversum, Leeuwarden, Oss, Utrecht en Veenendaal. De andere negen rekenkamerrapporten gingen niet of te beperkt in op de doorwerkingsfactoren. Zij beperkten zich veelal tot raadsbehandeling en tot het meten van de kale implementatie van de aanbevelingen, zonder de verklarende factoren voor de doorwerking te onderzoeken. Hieronder wordt ingegaan op de eerder onderscheiden drie categorieën van factoren van gebruik: (1) factoren van evaluatiekwaliteit, (2) factoren die te maken hebben met de context, en tot slot (3) het betrekken van de stakeholders bij de evaluatie.

\subsection{Factoren van evaluatiekwaliteit}

De factoren van de categorie evaluatiekwaliteit die doorwerking positief beïnvloeden, komen het vaakst terug in de doorwerkingsonderzoeken van de twintig rekenkamers.

\section{- Communicatiekwaliteit}

Het belang van de communicatiekwaliteit wordt vaak onderschreven, in negen van de elf rapporten is hier aandacht voor. Het gaat dan ook om de essentie van rekenkamerwerk: de duidelijkheid van de tekst in het rapport, de bevlogenheid waarmee de rekenkamer de bevindingen en aanbevelingen over het voetlicht brengt, en de verschillende manieren waarop de rekenkamer haar boodschap verspreidt. Deze factor bepaalt zowel de navolgbaarheid als de zichtbaarheid van de rekenkamer. Dat dit lastig balanceren is, ondervond de rekenkamer van Deventer. Daar werden de presentaties van de rekenkamer gewaardeerd door de raad, maar de communicatie over het kritische rapport naar buiten toe (zoals de pers) werd niet zo gewaardeerd door het college en sommige fracties. Daarin was Deventer niet alleen: de kwaliteit van de communicatie over rekenkamerrapporten wordt in de doorwerkingsonderzoeken vaak genoemd als belangrijke factor.

\section{- Gedetailleerde, op feiten gebaseerde, bruikbare aanbevelingen}

Minder verbazingwekkend, gezien het hoge aantal geïmplementeerde aanbevelingen, is het belang dat wordt gehecht aan gedetailleerde, op feiten gebaseerde, concrete aanbevelingen. Deze worden in negen van de elf rapporten genoemd als positief voor de doorwerking. Hoe belangrijk dat is, illustreert de rekenkamer van Maastricht, die in haar doorwerkingsonderzoek ziet dat ze soms aanbevelingen als wens of als discussiepunt formuleert, waardoor het onduidelijk is wat er precies van het college verwacht wordt en de raad hierop ook niet goed kan controleren.

\section{- $\quad$ Tijdigheid}

Het belang van timing, zodat een rekenkameronderzoek plaatsvindt op een moment dat de raad er behoefte aan heeft, wordt eveneens in negen van de elf zelfevaluaties genoemd als belangrijk element voor de doorwerking van de rapporten. De rekenkamercommissie van Doetinchem concludeerde bijvoorbeeld 
dat de doorwerking van de rapporten groter was als die aansloten bij actuele thema's in de raad.

\section{- Competentie van de evaluator}

De competentie van de evaluator is in vier zelfevaluaties onderschreven. Zo werd de rekenkamercommissie Veenendaal door de gemeenteraad, het college en de ambtenaren als 'deskundig' gezien, en werd de rekenkamer van Hilversum door deze betrokkenen als 'zorgvuldig', 'gedegen' en 'onafhankelijk' gekenmerkt. De methodologische kwaliteit wordt iets vaker genoemd in de evaluaties, namelijk zes keer. Deze wordt doorgaans als goed beschouwd.

Of de bevindingen van de rekenkamer stroken met de verwachtingen van de gemeenteraad en het college, kwam slechts in twee doorwerkingsonderzoeken voor als factor voor doorwerking. Zo meenden het college en de ambtenaren in Veenendaal dat de bevindingen van de rekenkamer soms achterhaald waren door ontwikkelingen in het beleid. De relevantie voor de besluitvorming werd in de doorwerkingsonderzoeken zes keer genoemd als factor die de doorwerking van rekenkameronderzoek verklaart. Echter, die laatste factor bleek in de praktijk eigenlijk niet te scheiden van de factor tijdigheid. Relevantie werd namelijk vaak uitgelegd in termen van actualiteit. De geloofwaardigheid werd in twee rapporten expliciet genoemd en viel samen met de competentie en (methodologische) kwaliteit van de rapporten.

Samenvattend zien we, net als in de literatuur, dat niet alle factoren even zwaar wegen. De top van doorwerkingsfactoren die de rekenkamers zelf noemen, komt overeen met die in de evaluatieliteratuur: communicatiekwaliteit, bruikbare aanbevelingen en tijdigheid worden ook hier het vaakst genoemd. Opvallend is verder dat relevantie voor de besluitvormer relatief vaker voorkomt dan in de literatuurreview. Dit is wel verklaarbaar: de rekenkamercommissie werkt immers in een politieke omgeving en kiest haar onderwerp heel vaak na een rondje langs de raad(fracties). De raad hecht doorgaans aan meer zicht op actuele dossiers.

\subsection{Factoren in de context van het onderzoek en de besluitvorming}

Van de zes factoren uit de literatuur die te maken hebben met de context, komen er drie terug in de bestudeerde doorwerkingsonderzoeken: het commitment en de openheid van de organisatie, het politieke klimaat en, weliswaar indirect, de informatiebehoefte van de gebruiker.

\section{- Commitment en openstaan van de organisatie voor evaluaties}

In de rekenkamerrapporten wordt het commitment van de organisatie het vaakst vertaald als de houding van de ambtenaren, terwijl bij politiek klimaat de houding van de gemeenteraad is bekeken. Wat hierbij opvalt, is dat de ambtelijke mening over de rekenkamerrapporten altijd zuiniger is dan die van de gemeenteraad, die over het algemeen behoorlijk tevreden is over de rekenkamer. In de zeven rapporten waarin de mening van ambtenaren over de kwaliteit van de rekenkamer en haar rapporten werd gevraagd, was deze vijfmaal positief, maar werden er ook kanttekeningen geplaatst. In Deventer en Ede ging dat over de overbodigheid 
of achterhaaldheid van aanbevelingen, en in Utrecht stelden ambtenaren de gedetailleerdheid van de aanbevelingen en de belerende toon van de rekenkamer ter discussie. In Ede, Hilversum, Utrecht en Veenendaal werd de afstand tussen rekenkamer en ambtenarij als te groot gekwalificeerd door de ambtenaren of was er soms ambtelijke onbekendheid met de rekenkamer of haar rapporten.

\section{- Politiek klimaat}

De bestudeerde doorwerkingsrapporten laten zien dat gemeenteraadsleden over het algemeen tevredener zijn over de rekenkamer dan de ambtelijke organisatie. Wat verder opvalt, is dat de politieke cultuur, de omgangsvormen en gewoonten van een gemeente erg verschillen en ook van invloed zijn op de doorwerking van de rekenkamerrapporten. Zo liet de rekenkamercommissie Medemblik het aan het college over om het raadsvoorstel over de rapporten op te stellen, iets wat bijvoorbeeld in Utrecht ondenkbaar is. Ook is de betrokkenheid van de ambtenaren en raadsleden bij de rekenkamer in de ene gemeente veel groter dan in de andere. Dat zie je terug in de rol van het voorgesprek dat een rekenkamer bij de start van een onderzoek voert, wel of geen presentatie door de rekenkamer in de gemeenteraad, de behandelwijze in commissies en de eventuele besluitvorming in de raad.

Dat de besluitvorming helder moet zijn, is ook erg belangrijk voor de doorwerking. Zo concludeerde de rekenkamercommissie van Cranendonck dat bij een rommelige besluitvorming de doorwerking niet plaatsvond. Bij de meerderheid van de rapporten had daar zelfs geen bestuurlijke wederhoor plaatsgevonden. In Opmeer vond de behandeling van het rekenkamerrapport over grondexploitaties in beslotenheid plaats, waardoor de besluitvorming en daarmee de opvolging voor de rekenkamercommissie niet navolgbaar waren.

\section{- Informatiebehoefte van de gebruiker}

De informatiebehoefte van de gebruiker, hier de gemeenteraad, komt indirect in twee evaluaties terug als verklaringsfactor voor de beleidsmatige doorwerking. Daarnaast is het opvallend vaak een aanbeveling aan zichzelf om als rekenkamer de gemeenteraad nog meer bij het rekenkamerwerk te betrekken. Zo denken de rekenkamers van Leeuwarden, Deventer en Oss dat het effectiever is om vooraf bij de gemeenteraad onderzoeksonderwerpen op te halen of - zoals in Deventer de raad hier beter bij te betrekken. In bijvoorbeeld Deventer en Doetinchem werd de onderzoeksopzet niet met de gemeenteraad gedeeld en gold dit als verbeterpunt.

Samenvattend kunnen we stellen dat in de doorwerkingsrapporten met name aandacht is voor de factoren commitment en openheid van de organisatie, politiek klimaat en informatiebehoefte van de gebruiker. De factor 'persoonlijke kenmerken van de evaluator' wordt ook regelmatig benoemd, maar meer in termen van competentie en methodologische kwaliteit. 


\subsection{Betrekken van stakeholders bij het rekenkamerrapport}

In diverse doorwerkingsrapporten wordt gewezen op het belang van het betrekken van stakeholders bij een onderzoek voor de mate van doorwerking. In vijf gevallen wordt hier de gemeenteraad bedoeld. Daarbij gaat het dan vooral om manieren om de gemeenteraad beter bij de onderwerpkeuze of onderzoeksopzet te betrekken. Andere stakeholders die vaak voorbijkomen, zijn de ambtelijke organisatie (startgesprek) en het college van B\&W.

De rekenkamer van Hilversum merkte dat het aanstellen van een ambtelijk secretaris de benaderbaarheid en zichtbaarheid van de rekenkamer voor de ambtelijke organisatie vergrootte. De gemeente Utrecht heeft voor haar ambtenaren een handreiking gemaakt over de taken en bevoegdheden van de rekenkamer, en de omgang met de rekenkamer. De rekenkamer van Hilversum beschrijft dat de ambtelijke organisatie van Hilversum ambtelijke wederhoor een ineffectief en tijdrovend proces vond; als experiment is daarom een wederhoorsessie gehouden waarbij ambtenaren en rekenkamer in gesprek kwamen over de manier waarop de rekenkamer omging met de wederhoor. In Hilversum krijgt het college een 'warme overdracht', waarbij de rekenkamer aan de portefeuillehouder de bevindingen en aanbevelingen toelicht opdat deze beter 'landen' bij het bestuur en ook de ambtelijke organisatie. Ook in bijvoorbeeld Utrecht is dit gebruikelijk.

De rekenkamers beperken zich, zo blijkt uit de doorwerkingsrapporten, tot de meer traditionele stakeholders; bedrijven of burgers worden eigenlijk niet genoemd. Er is wel aandacht voor de media, maar deze worden eigenlijk alleen passief betrokken door een persbericht uit te sturen. De enige stakeholder die systematisch wordt besproken, is de gemeenteraad, die over het algemeen positief is over de rol van de rekenkamer en de kwaliteit en doorwerking van de rapporten. Daarmee wordt deze factor breed onderschreven als belangrijk voor het bijdragen aan de doorwerking.

\section{Conclusie en discussie}

Rekenkamers willen met hun onderzoeksrapporten bijdragen aan de kwaliteit van het lokaal of provinciaal bestuur. Om die reden is het belangrijk om te weten hoe we de doorwerking van rapporten, of juist het gebrek hieraan, kunnen verklaren. Die vraag is wetenschappelijk relevant, maar draagt nadrukkelijk ook bij aan meer inzicht bij rekenkamers zelf hoe zij hun impact kunnen vergroten. In de loop van de jaren is er wel onderzoek gedaan naar de doorwerking van de rapporten van decentrale rekenkamers, maar door verschillende definities en onderzoeksmethoden zijn de conclusies daarvan niet eenduidig. In dit artikel is daarom systematisch onderzocht wat rekenkamers over hun eigen doorwerking rapporteren. Daarbij is gebruikgemaakt van een toetsingskader dat is gebaseerd op de literatuur over het gebruik van (beleids)evaluaties.

Een eerste conclusie is dat de aanbevelingen van rekenkamers bijna altijd worden overgenomen door de gemeenteraad. Dat deze zogenaamde procedurele doorwer- 
king hoog blijkt te zijn, sluit volledig aan op eerdere bevindingen uit landelijke evaluaties (Brandsen e.a., 2007; Van der Zee \& De Jong, 2010; Van der Mark e.a., 2011; Van der Mark \& De Wal, 2015). Dat de rekenkamers zelf rapporteren dat driekwart van hun aanbevelingen ook werden uitgevoerd door het gemeentebestuur, is verrassender. Bij deze conclusie moet de belangrijke kanttekening worden gemaakt dat veel van de rekenkamers deze conclusie baseerden op door het bestuur of de ambtelijke organisatie aangeleverde gegevens. Dat maakt dat overrapportage op de loer ligt. Zelfevaluaties als deze doorwerkingsonderzoeken hebben van nature namelijk de neiging om te optimistisch te zijn (Wildavsky, 1972).

Als we verder kijken, valt op dat de rekenkamers vooral doorwerkingsfactoren identificeren die samenhangen met de kwaliteit van hun onderzoeksrapporten. De communicatiekwaliteit, helderheid van de aanbevelingen, tijdigheid en relevantie voor de besluitvormer (de raad) worden hierbij het vaakst genoemd. Deze conclusie is in zekere zin niet verrassend: het zijn factoren die betrekking hebben op de kern van het rekenkamerwerk, de onderzoeksrapporten en de communicatie daarover. Het zijn bovendien zaken die voor een rekenkamer beïnvloedbaar zijn en daarom in een (zelf)evaluatie altijd zullen worden meegenomen.

Naast de kwaliteit van hun onderzoeken zien de rekenkamers ook een belangrijke rol voor omgevingsfactoren die kunnen worden samengevat als de ontvankelijkheid van de gemeentelijke organisatie en het politieke klimaat in de gemeente. Dat sluit aan bij de organisatiekundige literatuur over leren in publieke organisaties (Rashman e.a., 2009). De wil om te leren hangt sterk samen met de wil om beleid te veranderen (Bennett \& Howlett, 1992). De organisatiecultuur is een belangrijke voorspeller van de vraag of een organisatie een evaluatie opvat als een impuls voor leren of afrekenen (Greiling \& Halachmi, 2013). Dat is ook in (rekenkamer)onderzoek een bekend dilemma (Van der Steen \& Van der Duin, 2012). Daarbij maakt het wel verschil welke actoren het betreft: de doorwerkingsrapporten laten zien dat de gemeenteraad in het algemeen positiever is over het rekenkameronderzoek dan het college en zijn ambtenaren. Dat illustreert de noodzaak van het belang om de voornaamste stakeholders er goed bij te betrekken, een conclusie die uit de doorwerkingsrapporten kan worden getrokken. Dat geldt niet alleen voor de gemeenteraad. Rekenkamers zouden zich met name ook moeten inspannen om de ambtenaren en het college het nut van hun onderzoeken te laten inzien.

Interessante vragen voor vervolgonderzoek betreffen de hiërarchie en het samenspel van de diverse factoren die doorwerking bevorderen: Is de kwaliteit van de producten belangrijker dan politiek-bestuurlijke omgevingsfactoren? Of is kwaliteit een noodzakelijke voorwaarde die niet zonder een open organisatiehouding en politiek-bestuurlijk klimaat kan? En hoe creëer je dat laatste, als dat er (nog) niet is? Meer aandacht voor de belangrijke factor van het betrekken van stakeholders is een nuttige aanbeveling, maar hoe zorg je er dan voor dat het ook effectief is? In de doorwerkingsonderzoeken is bijvoorbeeld vrij weinig aandacht voor de persoonlijke relatie met ambtenaren én bestuurders, terwijl we weten dat zij 
een sleutelrol spelen in de bereidheid van de gemeentelijke organisatie om daadwerkelijk iets te doen met de aanbevelingen (Sanderson, 2002).

Dit alles sluit aan bij stromingen die aandacht vragen voor het idee dat evaluaties ook inherent politiek zijn. Dit geldt nog sterker voor onderzoeken die gaan over de doeltreffendheid en doelmatigheid van beleid (Taylor \& Balloch, 2005; Weiss, 1993). Een benadering die rekenkameronderzoek als een politiek verschijnsel centraal stelt, zou meer aandacht kunnen schenken aan de vraag waarom sommige onderzoeken en aanbevelingen volledig worden geïmplementeerd en andere min of meer doodvallen in de raad of ambtelijke organisatie. Dat sluit ook aan bij de politiek-strategische vorm van doorwerking van Bekkers e.a. (2004). Rekenkamers zouden op dit punt mogelijk nog meer van elkaar kunnen leren. Ook de verschillen tussen gemeentelijke afdelingen in de mate van bereidheid om van evaluaties te leren zouden doorwerking verder kunnen verklaren (House e.a., 1996). Meer inzicht in deze aspecten zou de effectiviteit van rekenkamers verder kunnen vergroten.

\section{Lessen voor de praktijk}

Uit de conclusie en dit onderzoek zijn een paar belangrijke lessen voor de praktijk te halen. Die kunnen een rekenkamer helpen om doorwerking te stimuleren.

1 Zorg dat er een goed contact is met de gemeenteraad; dit is een aandachtspunt dat uit veel doorwerkingsonderzoeken naar voren komt.

2 Dé succesfactor die de rekenkamer zelf kan beïnvloeden, is een helder geschreven rapport met een handelingsperspectief. Het verspreiden van dit rapport door presentaties te geven en de pers te informeren loont.

3 Rekenkamers werken in een politieke context; daarom zijn tijdigheid en relevantie van rekenkameronderzoeken een belangrijke voorspeller voor doorwerking.

4 Maar dat is niet voldoende; de politieke cultuur en ambtelijke organisatiecontext lijken nog belangrijker om gedragen en uitgevoerde aanbevelingen te krijgen. Zorg daarom dat de afstand tot de ambtenaren beperkt is. Onbekend maakt hier onbemind.

5 Zorg voor een heldere besluitvorming en zorg dat de gemeenteraad expliciet een besluit neemt over de conclusies en aanbevelingen, bijvoorbeeld door als rekenkamer zelf het raadsvoorstel te schrijven.

6 De laatste stap om doorwerking te bevorderen is monitoring door bijvoorbeeld de griffie of de aanbevelingen ook daadwerkelijk worden geïmplementeerd.

\section{Literatuur}

Alkin, M.C. \& J.A. King, 'Definitions of evaluation use and misuse, evaluation influence, and factors affecting use', American Journal of Evaluation, 2017/3, p. 434-450. 
Alkin, M.C. \& S.M. Taut, 'Unbundling evaluation use', Studies in Educational Evaluation, 2003/1, p. 1-12.

Bekkers, V.J.J.M., H.J.M. Fenger, V.M.F. Homburg \& K. Putters, Doorwerking van strategische beleidsadvisering, Amsterdam: 2004.

Bennett, C. J., \& M. Howlett, 'The lessons of learning. Reconciling theories of policy learning and policy change', Policy Sciences, 1992/3, 275-294.

Brandsen, T., P. Kalders, L. Schaap \& R. Schouten, Leren afrekenen. Een voorlopige evaluatie van lokale en provinciale rekenkamer(commissie)s, Den Haag: 2007.

Cousins, J.B. \& K.A. Leithwood, 'Current empirical research on evaluation utilization', Review of Educational Research, 1986/3, p. 331-364.

Fleischer, D.N. \& C.A. Christie, 'Evaluation use. Results from a survey of US American Evaluation Association members', American Journal of Evaluation, 2009/2, p. 158-175.

Greiling, D. \& A. Halachmi, 'Accountability and organizational learning in the public sector', Public Performance \& Management Review, 2013/3, p. 380-406.

Hakvoort, J.L.M. \& H. Klaassen, 'Doorwerking van lokaal rekenkameronderzoek', TPC, 2008/5, p. 23-27.

Henry, G T. \& M.M. Mark, 'Beyond use. Understanding evaluation's influence on attitudes and actions', American Journal of Evaluation, 2003/3, p. 293-314.

Hoekstra, R., 'Wat is de meerwaarde van onze rekenkamer? Introductie van een model om de doorwerking van rekenkameronderzoek te meten', Beleidsonderzoek Online, oktober 2013.

Højlund, S., 'Evaluation use in the organizational context. Changing focus to improve theory', Evaluation, 2014/1, p. 26-43.

House, E.R., C. Haug \& N. Norris, 'Producing evaluations in a large bureaucracy', Evaluation, 1996/2, p. 135-150.

Johnson, K., L.O. Greenseid, S.A. Toal, J.A. King, F. Lawrenz \& B. Volkov, 'Research on evaluation use. A review of the empirical literature from 1986 to 2005', American Journal of Evaluation, 2009/3, p. 377-410.

Kamerstukken II 2014/15, 34000 VII, nr. 54, Brief van de minister van Binnenlandse Zaken en Koninkrijksrelaties. Actieplan rekenkamers, Den Haag: 2015.

Lemmens, E., 'Voorwerking, werking en doorwerking. Een praktisch instrument voor het meten van het effect van rekenkamers', Beleidsonderzoek Online, april 2014.

Mark, R. van der \& W. de Wal, Onderzoek naar budgetten en samenwerking van gemeentelijke rekenkamers en rekenkamercommissies. Eindrapport, Utrecht: 2015.

Mark, R. van der, A. Oostdijk, R. Beerepoot \& H. Heins, Evaluatie van de provinciale en gemeentelijke rekenkamers. Eindrapport, Utrecht: 2011.

Nederlandse Vereniging van Rekenkamers en Rekenkamercommissies (NVVR), Meten van doorwerking van rekenkamerproducten. Samenvatting, Ede: 2015.

Nederlandse Vereniging van Rekenkamers en Rekenkamercommissies (NVVR), Handreiking meten van doorwerking rekenkamerproducten, Ede: 2018.

Patton, M.Q., Utilization-focused evaluation, Thousand Oaks, CA: 1997.

Patton, M.Q., Essentials of utilization-focused evaluation, Thousand Oaks, CA: 2011.

Pawson, R. \& N. Tilley, Realistic evaluation, Thousand Oaks, CA: 1997.

Rashman, L., E. Withers, \& J. Hartley, 'Organizational learning and knowledge in public service organizations. A systematic review of the literature', International Journal of Management Reviews, 2009/4, p. 463-494.

Sanderson, I., 'Evaluation, policy learning and evidence-based policy making', Public Administration, 2002/1, p. 1-22.

Shulha, L.M. \& J.B. Cousins, 'Evaluation use. Theory, research, and practice since 1986', Evaluation Practice, 1997/3, p. 195-208. 
Steen, M.A. van der \& P. van der Duin, 'Learning ahead of time. How evaluation of foresight may add to increased trust, organizational learning and future oriented policy and strategy', Futures, 2012/5, p. 487-493.

Taut, S.M. \& M.C. Alkin, 'Program staff perceptions of barriers to evaluation implementation', American Journal of Evaluation, 2003/2, p. 213-226.

Taylor, D. \& S. Balloch (eds.), The politics of evaluation. Participation and policy implementation, Bristol: 2005.

Weiss, C.H., 'Where politics and evaluation research meet', Evaluation Practice, 1993/1, p. 93-106.

Werkgroep lokale rekenkamers, De stand van zaken m.b.t. lokale rekenkamers, op basis van een landelijke gespreksronde, Utrecht: 2019.

Wildavsky, A., 'The self-evaluating organization', Public Administration Review, 1972/5, p. 509-520.

Zee, T. van der \& E. de Jong, Een spiegel van het rekenkamerlandschap, Byond, Groningen: 2010.

\section{Geanalyseerde rekenkamerrapporten}

Rekenkamercommissie Gemeente Deventer, Je kunt een paard naar het water leiden maar je kunt het niet dwingen te drinken. Evaluatie Rekenkamercommissie 2010-2014, Deventer: 2014.

Rekenkamercommissie Cranendonck, Naar meer rendement van rekenkameronderzoek, Budel: 2014.

Rekenkamer Maastricht, Uitvoering aanbevelingen rekenkamerrapporten, Maastricht: 2014.

Rekenkamer Nieuwkoop, Effect rekenkamerrapporten 2010-2014. Eindrapport, Nieuwkoop: 2014.

Rekenkamercommissie 's-Hertogenbosch, Quick scan doorwerking, Den Bosch: 2015.

Rekenkamercommissie Medemblik-Opmeer, Eindrapport. Opvolging RKC-onderzoeken in de gemeente Medemblik, periode 2012-2014, Medemblik: 2015.

Rekenkamercommissie Medemblik-Opmeer, Eindrapport. Opvolging RKC-onderzoeken in de gemeente Opmeer, periode 2012-2014, Opmeer: 2015.

Rekenkamer Doetinchem, Van aanbeveling naar actie. Onderzoek naar de doorwerking van onderzoeksrapporten van de rekenkamer. Onderzoeksgegevens, bevindingen en aanbevelingen van de rekenkamercommissie Doetinchem, Doetinchem: 2016.

Rekenkamer Hilversum, Evaluatie Rekenkamer Hilversum, Hilversum: 2016.

Rekenkamercommissie 's-Hertogenbosch, Met focus vooruit! Vervolgonderzoek Regionaal economisch beleid gemeente 's-Hertogenbosch, Den Bosch: 2016.

Rekenkamer Breda, De doorwerking van de onderzoeken van de Rekenkamer Breda, Breda: 2016.

Rekenkamercommissie Oss, Rituele dans of samenspel? Evaluatie doorwerking rekenkameronderzoeken 2011-2015, Oss: 2016.

Rekenkamer Zeist, Implementatieonderzoek naar financiële projectbeheersing. Rekenkameronderzoek naar de uitvoering van de aanbevelingen uit het onderzoek 'Richtingwijzers voor kaderstelling' en een verkenning naar de financiële (project)beheersing in de gemeente Zeist, Zeist: 2016.

Lokale Rekenkamer Leerdam, Rekenkamerbrief doorwerkingsonderzoek Onderwijsachterstanden, Leerdam: 2017.

Lokale Rekenkamer Leerdam, Plausibiliteit bezuinigen. Doorwerkingsonderzoek, Leerdam: 2017.

Rekenkamercommissie Ede, Uit de la gekomen. Een onderzoek naar de doorwerking van rekenkameronderzoek in de gemeente Ede, Ede: 2017. 
Rekenkamercommissie Veenendaal, Functioneren en doorwerking van de rekenkamercommissie van Veenendaal, Veenendaal: 2017.

Rekenkamer Metropool Amsterdam, Terugblik RMA 2011-2016, Amsterdam: 2018.

Rekenkamer Leeuwarden, Wat doen we er uiteindelijk mee? Doorwerkingsonderzoek, Leeuwarden: 2018.

Rekenkamercommissie Schiedam-Vlaardingen, Doorwerkingsonderzoek aanbevelingen Rekenkamercommissie Schiedam-Vlaardingen in de gemeente Vlaardingen, Vlaardingen: 2019.

Rekenkamercommissie Schiedam-Vlaardingen, Doorwerkingsonderzoek aanbevelingen Rekenkamercommissie Schiedam-Vlaardingen in de gemeente Schiedam, Schiedam: 2019.

Rekenkamer Utrecht, Opvolgingsonderzoek Rekenkamerrapporten 2014-2018. Inzicht in de doorwerking van rekenkameronderzoek en de opvolging van raadsbesluiten, Utrecht: 2020. 